\title{
USING DYNAMIC CONTENT TO INCREASE RELEVANCE
}

\author{
Matsyi 0. \\ Kharkiv National Automobile and Highway University
}

\begin{abstract}
This article explores the process of using dynamic content to increase the relevance and conversion rate of a web resource. The main advantage of this approach is that it does not require the creation of additional pages of the site, increases the relevance of the content and, consequently, the likelihood of obtaining the effect of conversion.
\end{abstract}

Keywords: contextual advertising, traffic analysis, conversion, relevance.

\section{Introduction}

Internet marketing is the performance of consistent actions in solving marketing problems, using the capabilities of the Internet.

The main goal is to get the maximum effect from the potential audience of the site with the help of information and communication technologies (internet marketing tools).

The development of internet marketing has changed the way brands and companies use technology for marketing.

As digital platforms are increasingly included in marketing plans, digital marketing campaigns are becoming more widespread and effective.

Internet marketing techniques such as search engine optimization, content marketing, impact marketing, content automation, data marketing are becoming more common $[1,2]$.

The presented work investigates effective Internet marketing tools and site traffic analysis tools for the network of service stations (http://sto.kharkiv.ua/).

\section{Analysis of publications}

Typical applications of modern web technologies in industry are web-based applications for the control and management of various technological processes. For such applications, there is a problem of constructing a convenient, clear and simple user interface, which includes parameters, sensors, graphs, tables, while some of the parameters can be changed in real time [3].

Modern websites are characterized by the presence of a large number of audiovisual components, most of which are developed on HTML5 and various JS engines.

Given the complexity of the task, whole groups of programmers work on such projects, including designers, programmers, testers, etc. The quality of the final product formation depends on the quality of team formation [4-6].
One of the main characteristics of website optimization is the relevance of the pages and the conversion rate of user actions. Site page relevance is the relevance of a page to a search query.

This means relevance - the more the page matches the search query, the higher the site should be in the search results, since the page relevance value significantly affects the search ranking (sorting) [7].

Unhelpful pages with high semantic relevance can keep search relevance high until behavioral ranking factors are added to the relevance score. Where already the users will show the true benefits of the page by their behavior, as a result of which the text relevance will be supplemented and adjusted.

Increase page relevance through keyword density of text or increase relevance through links - measures that work in an environment of either low competition or high usability.

\section{Using dynamic content to increase relevance}

Dynamic content (dynamic content) is a subtype of content that is constantly updated depending on individual user factors: geo-position, online behavior and interests of the user, his gender, age, shopping history, current weather, etc.

With the help of dynamic content, you can effectively improve the interaction with consumers, providing them with information that is most relevant at the moment, this type of content is also called adaptive or smart content.

You can use dynamic content on site pages, in e-mails, advertisements, banners, pop-ups, etc.

The advantages of dynamic content include:

- immediate response to search queries and user actions;

- interactivity - the user gets the impression that he manages the content independently; 
- instant updates of information;

- direct influence on behavioral factors, which in turn affect the conversion;

- relieving users from the need to study uninteresting and unnecessary information [8].

Dynamic content is fully «approved» by search engines, if it is really designed with the interests of users in mind.

Of course, the development of dynamic content is more expensive than static, but in most cases, all costs are quickly offset, because «guessing» the wishes of users can significantly increase the conversion rate. «Smart» dynamic content adapts to certain users, showing them different images, generating calls to action and changing the text content according to the behavior and interests of the recipients.

The most personalized messages are guaranteed to attract the attention of consumers and raise the level of their involvement.

Introduction of constantly changing content allows:

- increase conversion (at least $4 \%$ ), making the user's network experience more relevant, increasing his intuitive understanding of what is happening and the number of relevant actions;

- keep the user on the site by bringing personalization to a new level: unique proposals, formed on the basis of user preferences;

- to give the consumer the opportunity to feel special due to individual appeals to him and his interests [8].

The main feature of this technology is that it does not require the creation of additional pages of the site, which significantly saves startup time and money.

With the use of dynamic content, the site's offer becomes relevant, the visitor sees on the site exactly what he was looking for in the search engine.

The average conversion using links with tags and dynamic headers and content is about $7-10 \%$.

UTM Tags Urchin Tracking Module is a tool for analyzing traffic sources, tags that are added to the address bar of a site or page to get detailed information about each traffic source. Creating UTM-tags helps you track and analyze site traffic.

The UTM tag itself means nothing, it's a regular link that only works in conjunction with Google Analytics or any other analytics service. With the help of a URL, you will be able to find out which post on social networks attracts more attention of your potential customers [9].

UTM tags are used for:
- tracking the effectiveness of the advertising campaign;

- analysis of the goals of the advertising campaign;

- adjusting the strategy of the advertising campaign.

Tags help you analyze the traffic your site receives in more detail. Find out where it comes from, on what keys, from what type of ads.

UTM tags are important for detailing data by traffic sources and channels. In Google Analytics, you can choose which report to watch - by source (source) or channels (medium). Source is information about who sent a visitor to the site. Channel (medium) - how it was done.

UTM-tag parameters are mandatory - they are always used; and optional - they can be customized. Mandatory parameters of UTMlabels provide the database required for analytics, and optional ones allow you to detail them even more.

In addition to the standard, there are also dynamic UTM-tags for Google, direct and social networks for more detailed information.

UTM tags, combined with dynamic content, can have a significant scope.

In the following example, you can see how the service station can set optimal values for prices for repair services using a combination of these technologies.

The block with the price list on the inner page of the «Repair» service contains a PHPscript, which with the help of GET request is able to obtain the value of an important UTMtag for research.

In our case, it's utm_content, which is standard for contextual advertising and Google analytics systems.

It can have three values (low-price, middleprice and high-price) at which, respectively, low, medium or high prices are set.

This is followed by the construction of IF with several conditions. After performing any of them, using the variables \$price (1-11) set certain price values.

Their output in the price list is carried out by means of standard constructions

$$
<\text { ? Php echo \$ price (1-11); ?>. }
$$

In case the UTM label is missing or has an unknown value, the default values of the $\$$ price variables (1-11) are specified in the IF construct.

This approach allows not only to analyze the dependence of user behavior on the price level 
(using Google Analytics), but also to compare the number of requests (using the contact form) for each price list.

To do this, add a hidden field input type $=$ «hidden» to the contact form. In the value parameter you need to insert the following phpcode:

$<$ ? Php \$ utm_content = \$ _GET ['utm_content']; echo \$utm_content; ?>.

For the most accurate analysis and tracking of the effectiveness of Google Ads advertising campaigns, you need to add hidden fields for other standard UTM tags in the same way:

- utm_source (source of the advertising campaign);

- utm_medium (type of advertising campaign);

- utm_campaign (name of the advertising campaign);

- utm_term (keyword).

Visually, nothing will change on the page. The form handler secretly reads the UTM tag information from the GET request and adds it to the data provided by the user.

To send information to e-mail, you must configure the form handler to retrieve data from hidden fields.

Values of new variables with UTM tags are already accepted by the POST method and sent via the mail function

(for example, \$ utm_content $=\$$ _POST ['utm_content']. "<br>";).

Thus, in addition to the data (phone, e-mail, messages) left by the user, the administrator's email will also be sent information about the source from which this user went to the site, the type and name of the Google Ads advertising campaign, keyword and price list, which he could see before sending the order.

To take into account orders for each price level (price list), which were received by phone and e-mail (not using the contact form), you must place another php-script (similar to the first) in the block with contact information.

For each possible value of the UTM-tag utm_content (low-price, middle-price and highprice) it is necessary to specify unique phone numbers and e-mail. This approach allows you to correctly identify users by price criterion.

Also, keep in mind that the default contact information must be present.
Once you have created three versions of the Repair page with UTM tags and dynamic content, with different pricing options and contact information, you need to create a thematic inbound traffic stream that can be shared equally between pages for further evaluation.

The best way to do this is to use Google Ads contextual advertising.

After signing in to your Gmail email account, you'll need to go to https://ads.google.com/ and create a Google Ads account to place your Google Ads campaign there. Its overall purpose is «Site Traffic», advertising is configured in the search network. Geographic targeting is further configured.

You must select «Maximum Clicks» as your bidding strategy.

Use the Google Ads Keyword Planner to generate a list of relevant keywords to add when you create a new ad group.

The standard form of links with utm-tags for Google Ads is as follows:

http://site.name/page?utm_source=google\&u tm_medium $=$ cpc\&utm_campaign $=\{$ campaignid \}$\& u t m \_$content $=\{$creative $\} \& u t m \_$term $=\{$keywo rd\}.

Replacing the standard templates of the page name and the value of the utm_content tags allows you to create links to three dynamic pages with a unique price value in the price lists:

http://site.name/remont?utm_source=google \&utm_medium=cpc\&utm_campaign=test $1 \& u t m$ _content $=$ low-price\&utm_term $=\{$ keyword $\}$

http://site.name/remont?utm_source=google \&utm_medium $=$ cpc\&utm_campaign=test $1 \& u t m$ _content $=$ middle-price \&utm_term $=\{$ keyword $\}$

http://site.name/remont?utm_source=google\&utm _medium=cpc\&utm_campaign=test $1 \& u t m \_$content $=$ high-price\&utm_term $=\{$ keyword $\}$.

You must create a separate ad in the group for each link. Headings and descriptions should be repeated in each of them. Once all three ads have been generated, so that the results of the study are as objective as possible, at the group settings level, it is necessary to disable ad optimization and thus ensure a uniform display of ads over an indefinite period of time.

\section{Conclusion}

Thanks to the implemented dynamic substitution of prices, contact data and fixing of UTMtags in the service station it is possible to assess 
the reaction of potential customers at different price levels, as well as to determine the desired number of customers at different levels of profitability.

It should also be noted that the above scheme can be used not only for the formation of the pricing policy of the service station, but also for the formation of services, testing the effectiveness of texts, images, promotional materials and any other content of the page.

\section{Література}

1. Севостьянов И. О. Поисковая оптимизация: практическое руководство по продвижению сайта в интернете. 3-е изд. Санкт-Петебург: Издательский дом «Питер», 2017. 270 с.

2. Секреты эффективного продвижения сайтов / Бабаев А. и др. Санкт-Петебург: Издательский дом «Питер», 2018. 60 с.

3. Мнушка О. В. Архітектура веб-орієнтованої SCADA-системи. Вісник Національного технічного університету «Харківський політехнічний інститут»: зб. наукових праць. Cер. Інформатика та моделювання. Харків: НТУ «ХПІ», 2018. № 24 (1300). С. 117-128. DOI: $\quad 10.20998 / 2411-0558.2018 .24 .10$ Харків: НТУ «ХПІ». 2020. № 1 (3). С. 99112. DOI: $10.20998 / 2411-0558.2020 .01 .09$.

4. Маций О. Б., Ніжников А. В. Огляд інформаційних сервісів для роботи 3 тривимірними моделями. Вісник Харківського національного автомобільно-дорожнього університету. Харків: ХНАДУ. Випуск 87. 2019. С. 43-49.

5. Ніжников А. В., Маций О. Б. Применение технологии WEBGL для разработки интерактивного веб-приложения: зб. наукових праць за матеріалами Міжнародної науковопрактичної конференції. Харків: ХНАДУ, 2019. C. 118-121.

6. Мнушка О. В., Савченко В. М. Формування та керування командою розробників програмного забезпечення. Вісник НТУ «ХПІ». Сер. Інформатика та моделювання. Харків: НТУ «XПI». 2020. № 1 (3). С. 99-112. DOI: 10.20998/2411-0558.2020.01.09.

7. Голополосов Д. 80 способов повысить конверсию сайта. Санкт-Петебург: Издательский дом «Питер», 2017. 130 с.

8. SEO - искусство раскрутки сайтов / Энж Э. и др. BHV, 2017. $816 \mathrm{c}$.

9. Ковилл А. Релевантность. Сила, которая меняет взгляды и поведение потребителей. Москва: Азбука, 2015. 226 с.

\section{References}

1. Sevostyanov I. O. Poiskovaya optimizaciya: prakticheskoe rukovodstvo po prodvizheniyu sajta $\mathrm{v}$ internete. 3-e izd. Sankt-Peteburg: Izdatelskij dom «Pi-ter», 2017. 270 s. [in Russian].
2. Sekrety effektivnogo prodvizheniya sajtov / Babaev A. i dr. Sankt-Peteburg: Izdatelskij dom «Pi-ter», 2018. 60 s. [in Russian].

3. Mnushka O.V. Arhitektura veb-oriyentovanoyi SCADA-sistemi. Visnik Nacio-nalnogo tehnichnogo universitetu «Harkivskij politehnichnij institut»: zb. naukovih prac. Ser. Informatika ta modelyuvannya. Harkiv: NTU «HPI». 2018. № 24 (1300). S. 117-128 DOI: 10.20998/2411-0558.2018.24.10- Harkiv: NTU «HPI». 2020. № 1 (3). S. 99-112. DOI: 10.20998/2411-0558.2020.01.09 [in Ukrainian].

4. Macyi O. B., Nizhnikov A. V. Oglyad informacijnih servisiv dlya roboti $\mathrm{z}$ trivimirnimi modelyami. Visnik Harkivskogo nacionalnogo avtomobilno-dorozhnogo universitetu. Harkiv: HNADU. Vipusk 87. 2019. S. 43-49 [in Ukrainian].

5. Nizhnikov A. V. Primenenie tehnologii WEBGL dlya razrabotki interaktiv-nogo veb-prilozheniya: zb. naukovih prac za materialami mizhnarodnoyi naukovo-praktichnoyi konferenciyi. Harkiv: HNADU, 2019. S. 118-121 [in Ukrainian].

6. Mnushka O. V., Savchenko V. M. Formuvannya ta keruvannya komandoyu rozrobnikiv programnogo zabezpechennya. Visnik NTU «HPI». Ser. Informatika ta modelyuvannya. Harkiv: NTU «HPI», 2020. № 1 (3). S. 99-112. DOI: $\quad 10.20998 / 2411-0558.2020 .01 .09$ [in Ukrainian].

7. Golopolosov D. 80 sposobov povysit konversiyu sajta. Sankt-Peteburg: Izdatelskij dom «Pi-ter», 2017. 130 s. [in Russian].

8. SEO - iskusstvo raskrutki sajtov / Enzh E. i dr. BHV, 2017. $816 \mathrm{~s}$.

9. Kovill A. Relevantnost. Sila, ko-toraya menyaet vzglyady i povedenie potrebitelej. Moskva: Azbuka, 2015. $226 \mathrm{~s}$.

Matsyi Olha, Candidate of Engineering Sciences, Associate Professor, Department of Computer Technology and Mechatronics, tel.: + 38-057-707-37-43, e-mail: olga.matsiy@gmail.com.

Kharkiv National Automobile and Highway University, 25, Yaroslava Mudrogo str., Kharkiv, 61002, Ukraine.

Використання динамічного контенту для підвищення релевантності

Анотація. Проблема. На сьогодні проблема підвищення релевантності або конверсії дій користувача веб-ресурсу є однією з найактуальніших. Релевантність сторінки в контексті оптимізації веб-ресурсів - ие досить складний параметр, за допомогою якого пошукові системи оцінюють релевантність пошукового запиту до сторінки веб-сайту. Існує думка, щуо синонімом слова релевантність є «адекватність» інформації. Зрештою саме висока релевантність сайту дозволяє досягти високих позицій у процесі пошуку. Чим 
більше сторінка відповідає запиту користувача, тим більша ймовірність отримати найкращчй результатів пошуку. Кожна пошукова система визначає актуальність запиту, сторінки та сайту за допомогою складних алгоритмів, тому можна лише здогадуватися, який вид роботи сприяє зростанню актуальності контенту та сайту. Існують різноманітні методи збільшення иього показника. Мета Метою роботи є розроблення веб-сайту для мережі СТО з механізмом підвищення актуальності контенту. Методологія. Під час розроблення сайту було запроваджено динамічне заповнення сторінок, яке, залежно від параметра, переданого за посиланням url, змінює раніше підготовлену інформацію. Динамічний вміст - ие підвид вмісту, який постійно оновлюється, залежно від таких індивідуальних факторів користувача, як геолокація, поведінка в інтернеті, стать, вік, історї покупок тощо. Завдяки механізму динамічної зміни вмісту за допомогою посилання url можна вибірково змінити зміст сторінки. Використання динамічного контенту покрашує взаємодію зі споживачами веб-ресурсу, надаючи інформацію, яка є найбільш актуальною. Цей тип вмісту називається адаптивним або розумним вмістом. Практичне значення. Головною перевагою изього підходу є те, щуо він не вимагає створення додаткових сторінок сайту, підвищує релевантність контенту, а отже, існує ймовірність отримати дію конверciï.
Ключові слова: веб-сайт, інтернет-маркетинг, аналіз трафіку, конверсія, релевантність.

Маций Ольга Борисівна, к.т.н., доцент кафедри комп'ютерних технологій i мехатроніки, тел.: +38-057-707-37-43,

e-mail: olga.matsiy@gmail.com.

Харківський національний автомобільнодорожній університет, вул. Ярослава Мудрого, 25, м. Харків, Україна.

\section{Использование динамического контента для} повышения релевантности

Аннотация. В представленной статье исследуется процесс применения динамического контента для повышения релевантности и показателя конверсии действий пользователя вебресурса. Главным преимуществом этого подхода является то, что он не требует создания дополнительных странии сайта, а также повышает релевантность контента.

Ключевые слова: веб-сайт, интернетмаркетинг, анализ трафика, конверсия, релевантность.

Маций Ольга Борисовна, к.т.н., доцент кафедры компьютерных технологий и мехатроники, тел.: +38-057-707-37-43,

e-mail: olga.matsiy@gmail.com.

Харьковский национальный автомобильнодорожный университет, ул. Ярослава Мудрого, 25 , Харьков, Украина. 